\title{
Identifikasi Praktik dan Hambatan Guru dalam Asesmen Kognitif Matematika di Masa Pandemi COVID-19
}

\author{
Hajra Yansa ${ }^{1 *}$, Heri Retnawati ${ }^{2}$ \\ ${ }^{1}$ Program Studi Penelitian dan Evaluasi Pendidikan, Universitas Negeri Yogyakarta \\ ${ }^{2}$ Fakultas Matematika dan Ilmu Pengetahuan Alam, Universitas Negeri Yogyakarta \\ *hajrayansa.2019@student.uny.ac.id
}

\begin{abstract}
Abstrak
Studi ini bertujuan untuk mengidentifikasi praktik dan hambatan guru dalam melakukan asesmen kognitif matematika di masa pandemi COVID-19. Jenis penelitian yang digunakan yaitu survey online menggunakan google form yang disebar selama sepuluh hari melalui WhatsApp. Survey ini menggunakan pendekatan kualitatif. Instrumen penelitan dikonstruk dari buku saku asesmen diagnosis kognitif berkala. Sejumlah 78 guru sekolah dasar sampai menengah dari berbagai wilayah di Indonesia berpartisipasi. Analisis data dilakukan secara deskriptif, sedangkan data dari pertanyaan terbuka dianalisis dengan software Atlasti 9. Hasil penelitian menyajikan praktik asesmen kognitif secara berkala dilaksanakan oleh guru matematika berbasis daring pada sekolah dasar kelas tinggi hingga sekolah menengah. Sedangkan, bagi sekolah dasar kelas rendah dilaksanakan secara home visit. Dalam praktiknya guru mengalami beberapa hambatan yaitu kevalidan jawaban, keterbatasan waktu dalam asesmen, hambatan dari peserta didik sendiri, dan fasilitas. Hambatan tersebut menimbulkan hasil asesmen belum mampu menggambarkan tingkat kognitif secara mendalam atau menyajikan informasi yang sahih dan dapat dipercaya perihal pencapaian peserta didik. Kata Kunci: asesmen matematika, COVID-19, kognitif, pendidikan matematika
\end{abstract}

\begin{abstract}
This study aims to identify teachers' practices and barriers in carrying out a cognitive mathematics assessment during the COVID-19 pandemic. The type of research used is an online survey using a google form, which is spread over ten days via WhatsApp. This survey uses a qualitative approach. The research instrument was constructed from a pocketbook of periodic diagnostic assessment. A total of 78 primary to secondary school teachers from various regions in Indonesia participated. Data analysis was done descriptively, while data from open questions were analyzed using Atlasti 9. The study results present the practice of cognitive assessment regularly carried out by online-based mathematics teachers in high-grade elementary schools to secondary schools. In contrast, low-grade elementary schools are conducted by home visit. In practice, teachers experience several obstacles: the validity of the answers, limited time in the assessment, barriers from students themselves, and facilities. These obstacles cause the assessment results not to describe the cognitive level in-depth or provide valid and reliable information regarding students' achievement.
\end{abstract}

Keywords: COVID-19, cognitive, mathematics education, mathematics assessment 


\section{Pendahuluan}

Corona Virus 2019 (COVID-19) pertama kali ditemukan di Wuhan, Provinsi Hubei, Republik Rakyat Cina (Huang et al., 2020: Rothan \& Byrareddy, 2020). Sedangkan di Indonesia kasus pertama terdeteksi pada awal Maret 2020, yang langsung diumumkan oleh Presiden Jokowi (Ihsanuddin, 2020). Penyakit yang disebabkan oleh COVID-19 semakin menggegerkan seluruh masyarakat dunia, semenjak Direktur Jenderal World Healt Organization (2020) mengumumkan sebagai pandemi. Maka untuk mengatasi penyebaran penyakit yang semakin luas, sebagian besar pemerintah di seluruh dunia telah memberlakukan lockdown, jaga jarak, menutup sekolah yang digantikan pembelajaran jarak jauh, dan pembatasan imigrasi (Gonzalez et al., 2020). United Nations Educational, Scientific and Cultural sebagai lembaga yang membawahi misi pengembangan pendidikan dunia, pun mendukung pendidikan jarak jauh dan penutupan sekolah. Hingga pada bulan April 2020 sebesar $84,5 \%$ dari populasi peserta didik di dunia mengalami dampak dari penutupan sekolah (UNESCO, 2020). Itulah puncak dampak penutupan sekolah selama pandemi berlangsung.

Pemerintah Indonesia juga menerapkan kebijakan yang sama melalui surat edaran No. 36962/MPK.A/HK/2020 yaitu menutup sementara waktu seluruh sekolah dan menganjurkan pembelajaran secara daring dari rumah. Faktanya, Belajar dari Rumah (BDR) tetap menjadi alternatif pilihan bagi pihak sekolah, bahkan BDR dapat berlanjut hingga tahun 2021. Tentunya, implementasi BDR berdampak pada perkembangan kognitif dan nonkognitif peserta didik, yang berlanjut mempengaruhi kualitas pendidikan Indonesia di masa yang akan datang. Hal ini terbukti dengan temuan studi sebelumnya telah menunjukkan kesenjangan proses pembelajaran selama BDR. Temuan Aji (2020) mengungkapkan terdapat gangguan dalam proses pembelajaran yang menurunkan kualitas keterampilan peserta didik dan berdampak pada psikologisnya. Hal serupa juga ditemukan dalam studi Purwanto et al. (2020), menunjukkan adanya kendala yang dihadapi peserta didik, guru, dan orang tua selama BDR terutama pada durasi mengajar guru. Jam kerja guru semakin bertambah karena harus berkoordinasi dengan pihak sekolah dan orang tua peserta didik.

Pada penyesuaian kebijakan pembelajaran di masa pandemi COVID-19 yang baru-baru ini disosialisasikan oleh Kemendikbud, asesmen berperan sebagai strategi pembelajaran di masa pandemi COVID-19 untuk melihat perkembangan peserta didik. Hal yang serupa juga sebelumnya digaungkan oleh Black dan Wiliam (2009) serta National Council of Teachers of Mathematics (NCTM, 2000) memandang asesmen sebagai tumpuan efektif untuk melakukan perubahan positif dalam pembelajaran, karena melalui asesmen guru memahami 
interkoneksi antara pengajaran, pengalaman belajar, dan kondisi psikologi peserta didik. Hasilnya digunakan untuk melihat kemajuan belajar terkait tujuan pembelajaran (Wilsey, Kloser, Borko, \& Rafanelli, 2020), serta tolak ukur keberhasilan penyelenggaraaan pendidikan (Sandberg \& Kecskes, 2017).

Terkait dengan pelaksanaan asesmen kognitif, Pusat Asesmen dan Pembelajaran (Pusmenjar,2020) merekomendasikan asesmen dilaksanakan secara berkala yang pelaksanaannya meliputi: (1) Persiapan yaitu tahapan penyusunan tes, pelaksanaan pengukuran secara daring atau tatap muka, dan tindak lanjut asesmen. Berdasarkan Keputusan Menteri Pendidikan dan Kebudayaan Republik Indonesia Nomor 719/P/2020, asesmen kognitif mata pelajaran matematika ditujukan untuk mengukur pencapaian kemampuan dan mendiagnosis kelemahan peserta didik dan diharapkan diharapkan memenuhi enam prinsip yaitu valid, reliabel, adil, fleksibel, otentik, terintegrasi. Berarti hasil asesmen harus menggambarkan tingkat kognitif secara mendalam atau menyajikan informasi yang sahih dan dapat dipercaya perihal pencapaian peserta didik. Tentunya, hal tersebut merupakan tantangan tersendiri bagi guru, sebagai penilai (Looney, Cumming, van Der Kleij, \& Harris, 2018; Xu \& Brown, 2016). Apalagi jika mempertimbangkan temuan studi sebelumnya yang menyajikan hambatan umum saat BDR yaitu keterbatasan pada sarana dan prasarana seperti peserta didik tidak memiliki gawai, terkendala pada kuota dan jaringan internet yang buruk (Atsani, 2020; Herliandry et al., 2020). Temuan dari Anugrahana (2020) tidak jauh berbeda, hasilnya menunjukkan tidak semua orang tua dan peserta didik mampu menggunakan berbagai aplikasi dalam pembelajaran, serta peserta didik sering mengalami kejenuhan dalam belajar daring.

Hambatan pembelajaran tersebut memberikan indikasi cukup sulit untuk mendapatkan gambaran pencapaian kognitif peserta didik. Bahkan kemungkinan guru masih mengalami hambatan lainnya dalam melaksanakan asesmen. Namun literatur yang mengulas secara khusus tentang pelaksanaan asesmen kognitif matematika di masa krisis ini masih sangat jarang. Oleh karena itu studi ini bertujuan untuk menjawab pertanyaan penelitian yang berkaitan praktik dan hambatan guru dalam asesmen kognitif matematika di masa pandemi COVID-19. Dengan menjawab pertanyaan penelitian tersebut didapatkan teknik menilai dan upaya yang ditempuh guru dalam menilai hasil belajar peserta didik saat COVID-19 guna menghasilkan hasil yang valid dan reliabel, serta hambatan lainnya yang dialami guru dalam melaksanakan asesmen.

\section{Metode}

Penelitian ini merupakan penelitian survey pendekatan kualitatif. Secara garis besar, terdapat empat tahap dalam penelitian ini yaitu persiapan, pengumpulan data, analisis data dan 
penarikan kesimpulan. Tahap persiapan meliputi penyusunan instrumen, kemudian menyajikannya dalam google formulir. Tujuh butir pernyataan/pertanyaan mewakili tiga aspek praktik asesmen kognitif selama pandemi COVID-19 dan satu butir mewakili aspek hambatan yang dialami oleh guru dalam menilai. Kuesioner dikonstruk berdasarkan buku saku asesmen diagnosis kognitif berkala (Pusmenjar, 2020). Indikator pada kuesioner disajikan pada tabel 1.

Tabel 1. Indikator pada kuesioner

\begin{tabular}{lll}
\hline No & Aspek & \multicolumn{1}{c}{ Indikator } \\
\hline & & Praktik asesmen \\
\hline 1 & persiapan & Membuat instrumen untuk mengukur pencapaian hasil belajar \\
\hline 2 & pelaksanaan & $\begin{array}{l}\text { Melaksanakan asesmen secara berkala } \\
\text { Menggunakan teknik asesmen } \\
\text { Menilai secara objektif }\end{array}$ \\
\hline 3 & Tindak lanjut & Membagi peserta didik dalam beberapa kategori/kelompok \\
\hline & & \multicolumn{1}{c}{ Hambatan dalam praktik asesmen } \\
\hline 4 & Hambatan & $\begin{array}{l}\text { Hambatan dalam mengukur pencapaian peserta didik di masa } \\
\text { pandemic COVID-19 }\end{array}$ \\
\hline
\end{tabular}

Instrumen yang digunakan merupakan kuesioner campuran, yaitu kombinasi pertanyaan tertutup dan terbuka. Kuesioner campuran memungkinkan responden untuk menulis jawaban yang tidak dengan pilihan-pilihan respon yang ada, serta untuk mendapatkan informasi yang lebih mendalam (Creswell, 2015). Pada butir pernyataan instrumen, ada beberapa pernyataan yang memberi kesempatan pada guru untuk memilih jawaban lebih dari satu dan penambahan jawaban, serta menanyakan alasan pemilihan jawaban. Sedangkan validitas instrumen ini menggunakan validitas tampang oleh dua ahli bahasa dan satu ahli asesmen matematika. Setelah direvisi selanjutnya digunakan untuk mengumpulkan data melalui penyebaran tautan kuesioner menggunakan Google Formulir yang dikirim ke guru melalui WhatsApp. Pengumpulan data dimulai tanggal 25 Agustus s/d 3 September 2020.

Terdapat 78 guru matematika di seluruh Indonesia yang mengajar di sekolah dasar hingga menengah mengikuti survey online ini. Profil responden digambarkan pada tabel 2, sedangkan sebaran responden di wilayah Indonesia digambarkan pada tabel 3.

Tabel 2. Profil responden

\begin{tabular}{llll}
\hline Jenis Kelamin (persentase) & $\begin{array}{l}\text { Pendidikan } \\
\text { terakhir } \\
\text { (persentase) }\end{array}$ & $\begin{array}{l}\text { Jenjang Satuan } \\
\text { Mengajar } \\
\text { (persentase) }\end{array}$ & $\begin{array}{l}\text { Proporsi Waktu } \\
\text { Mengajar (persentase) }\end{array}$ \\
\hline Laki-Laki $(37,2 \%)$ & S1 $(92,3 \%)$ & SD $(34,8 \%)$ & $<5$ tahun $(61 \%)$ \\
\hline Perempuan $(62,8 \%)$ & S2 $(7 \%)$ & SMP $(33,3 \%)$ & $5-10$ tahun $(18,2 \%)$ \\
\hline & & SMA $(31,9 \%)$ & $11-20$ tahun $(15,6 \%)$ \\
\hline & & & $>20$ tahun $(5,2 \%)$ \\
\hline
\end{tabular}


Tabel 3. Sebaran wilayah responden

\begin{tabular}{lcclcc}
\hline Provinsi & $\begin{array}{c}\text { Frekuensi } \\
(\mathbf{n})\end{array}$ & $\begin{array}{c}\text { Persentase } \\
(\mathbf{\%})\end{array}$ & Provinsi & $\begin{array}{c}\text { Frekuensi } \\
(\mathbf{n})\end{array}$ & $\begin{array}{c}\text { Persentase } \\
(\boldsymbol{\%})\end{array}$ \\
\hline Jawa Barat & 9 & 11 & Sumatera Barat & 2 & 3 \\
\hline Jawa Tengah & 3 & 3 & Sumatera Selatan & 4 & 5 \\
\hline DKI Jakarta & 4 & 5 & Maluku & 7 & 9 \\
\hline DIY & 8 & 10 & Sulawesi Tengah & 6 & 8 \\
\hline Jawa Timur & 2 & 3 & $\begin{array}{l}\text { Sulawesi } \\
\text { Tenggara }\end{array}$ & 2 & 3 \\
\hline Banten & 2 & 3 & Sulawesi Selatan & 21 & 27 \\
\hline Kalimatan Barat & 2 & 3 & Sulawesi Barat & 3 & 3 \\
\hline Sumatera Utara & I & 1 & Sulawesi Utara & 2 & 3 \\
\hline
\end{tabular}

Selanjutnya, data hasil survey diintrepetasi dan dianalisis secara deskriptif berdasarkan langkah yang dipaparkan oleh Creswell (2015) yaitu dengan melakukan koding dan mengkategorikan di dalam tema dengan meninjau kalimat dengan frekuensi terbanyak, tujuannya untuk mencari makna dan implikasi dari hasil penelitian. Dalam survey ini respon pertanyaan terbuka dikoding menggunakan software atlasti 9.

\section{Hasil Penelitian}

\section{Praktik asesmen kognitif matematika di masa COVID-19}

Hasil penelitian ini menunjukkan pada tahap persiapan asesmen kognitif bentuk tes yang digunakan oleh guru matematika untuk mengukur pencapaiah hasil belajar peserta didik lebih dominan pada uraian, sedangkan yang paling jarang yaitu soal benar-salah (gambar 1). Soal-soal yang dominan digunakan merupakan memodifikasi soal yang bersumber dari buku paket dan internet (gambar 2).

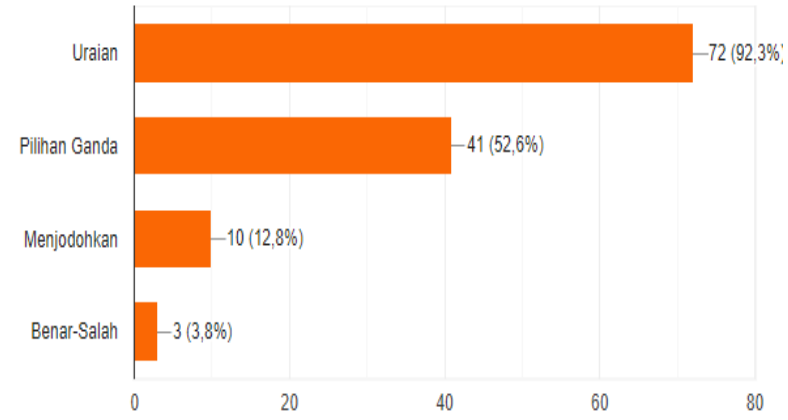

Gambar 1. Bentuk Tes

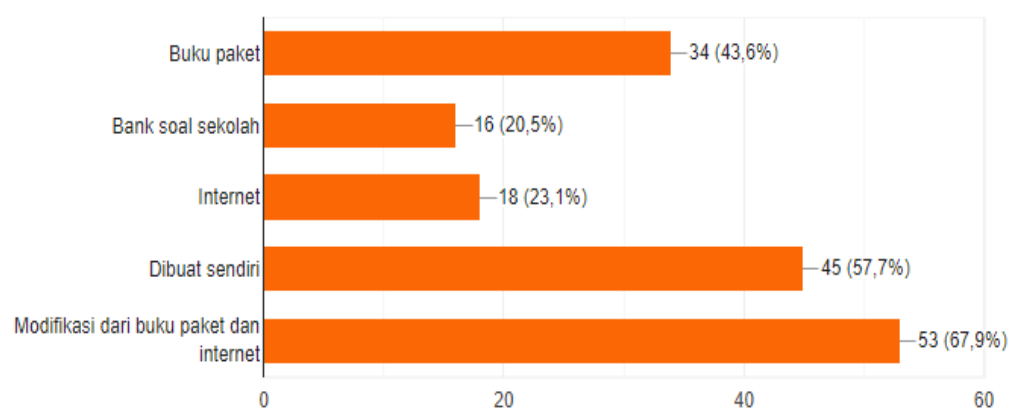

Gambar 2. Sumber Soal Tes

Pada tahap pelaksanaan pengukuran di masa pandemi COVID-19, guru melakukan asesmen dengan frekuensi terbanyak setiap mata pelajaraan berlangsung yang berarti usai penyampaian materi atau pengajaran, guru melakukan pengukuran terhadap pemahaman peserta didik. Namun frekuensi asesmen paling sedikit yaitu setiap dua bulan sekali (Gambar 
3). Teknik yang digunakan guru matematika dalam menilai didominasi oleh tes, selanjutnya portofolio, proyek, dan kinerja (Gambar 4).
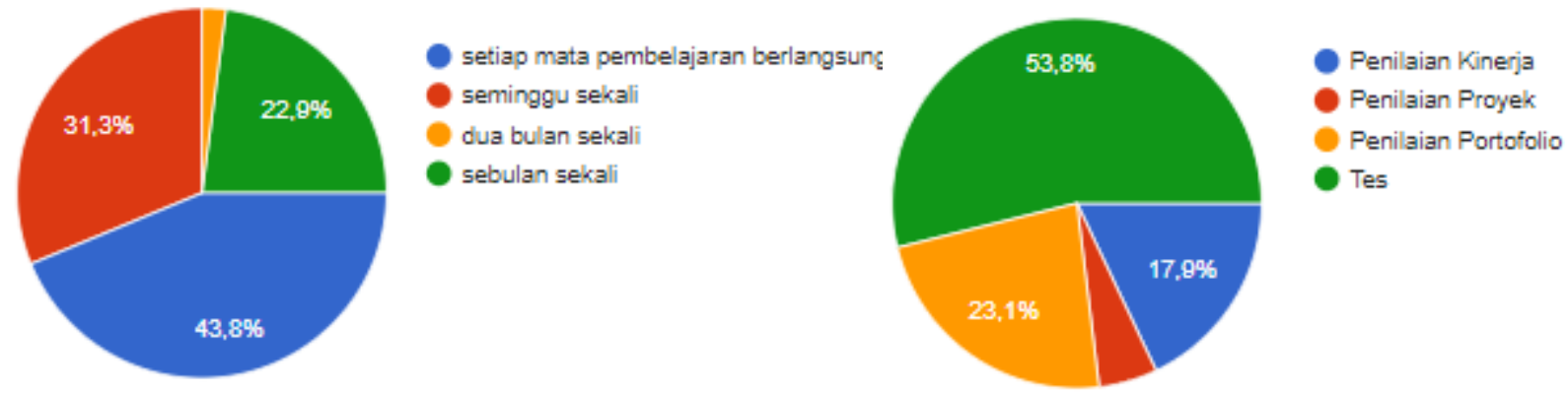

Gambar 3. Frekuensi asesmen

Gambar 4. Penggunaan teknik asesmen di masa COVID-19

Dari alasan penggunaan teknik asesmen, menunjukkan lebih dari setengah guru menggunakan teknik tes karena soal tes lebih mudah dibuat oleh guru, sederhana, serta sangat memudahkan dalam menilai karena menyajikan langkah-langkah pengerjaan peserta didik. Teknik asesmen portofolio digunakan karena dianggap efektif dan efisien dalam masa pandemi, guru dapat melihat keaktifan dari kumpulan tugas-tugas peserta didik. Sedangkan asesmen kinerja sebagai alternatif untuk mengetahui apakah siswa dapat mengerjakan secara mandiri, dengan asesmen kinerja guru dapat melihat secara langsung peserta didik bekerja memecahkan masalah. dan Asesmen proyek digunakan agar peserta didik lebih mengeksplorasi pengetahuan dalam belajar di rumah. Alasan-alasan tersebut yang mendasari guru menggunakan teknik asesmen di masa COVID-19.

Asesmen pada kelas rendah jenjang SD dilaksanakan melalui home visit, sedangkan pada kelas tinggi jenjang SD dan Sekolah Menengah asesmen berbasis daring menggunakan beberapa aplikasi. Berdasarkan analisis data dengan software Atlas.ti 9, pada gambar 5 menunjukkan aplikasi WhatsApp merupakan kata dengan frekuensinya paling banyak muncul, disusul google classroom. Alasan penggunaannya, karena aplikasi inilah yang familiar dan dapat dioperasikan oleh peserta didik dan pendamping (orang tua/sanak saudara) serta penggunaannya yang mudah.

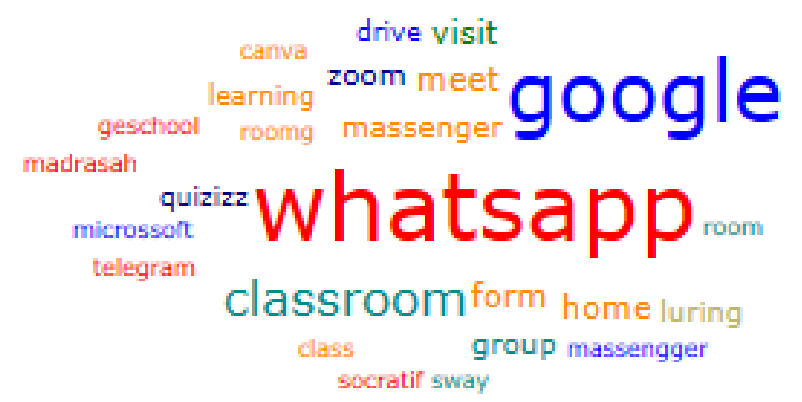

Gambar 5. Word cloud aplikasi yang digunakan 
Pada hasil jawaban terbuka perihal cara yang digunakan guru untuk meninjau keakuratan jawaban mereka saat asesmen jarak jauh dianalisis dengan atlasti.9 dengan melihat frekuensi terbanyak pada kata yang sering muncul berdasarkan word cloud pada gambar 6 , maka dapat diinterpretasi cara tersebut diantaranya:

- Memberi soal yang berbeda pada setiap peserta didik

- Memberi batasan waktu dalam tes, peserta didik yang paham cenderung mengumpulkan jawaban dengan cepat dengan jawaban yang tepat

- Mempertimbangkan keselarasan nilai dan keaktifan dalam proses pembelajaran

- Mempertimbangkan kerunutan prosedur dan penggunaan prinsip matematika, peserta didik yang paham langkah/penjabaran cenderung terstruktur tidak lompat-lompat.

- Saat memeriksa hasil pekerjaan dilakukan tes lisan/tanya jawab untuk menguji apakah tugas dikerjakan sendiri atau atas bantuan orang lain

- Pengawasan saat asesmen dengan mengaktifkan video confrence

\section{denganhasiltugasyang dalam dan mengumpulkan sesuaisiswa tes video waktu berdasarkan didik memberikan pada pekerjaan peserta portofolio akn apaka hatas atau bantuan benar berbeda confrence dari dikerjakan dikumpulkan dilaksanakan dilakukan diperoleh ditentukan evaluasi foto individu jawab jawaban keaktifan kecepatan kedisiplinan kerajinan ketepatan kinerja lain lalu lisan lompatlompat matematika media melihat memberi memeriksa mengerjakan mengerti menggunakan menguji menjawab menngerjakan orang pengawasan penilaian penjabaran penyelasaian portfolio portofoli pr prinsip prosedur proses proyek saat sendiri setiap soal tanya tersebut tertentu tidak untuk yg}

Gambar 6. Word cloud cara guru meninjau keakuratan hasil tes

Pada tahap tindak lanjut hasil asesmen, sebagian besar guru telah membagi peserta didik dalam beberapa kelompok atau kategori untuk selanjutnya dilakukan remediasi dalam kegiatan pembelajaran, hal ini ditunjukan pada gambar 7 .

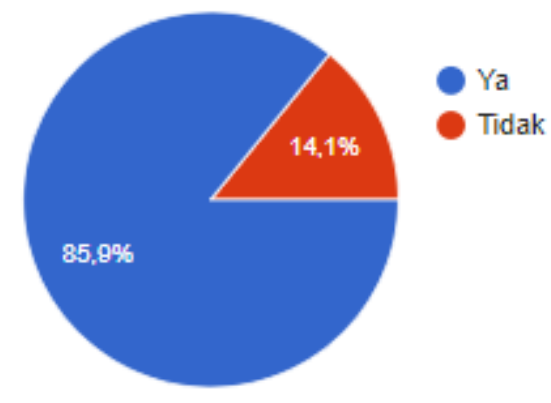

Gambar 7. Tindak lanjut hasil asesmen 


\section{Hambatan Asesmen Kognitif Matematika di Masa COVID-19}

Dalam pelaksanaan pengukuran asesmen guru meghadapi beberapa hambatan. Hambatan dibagi empat yaitu (1) Hambatan dalam kevalidan jawaban, (2) keterbatasan waktu, (3) hambatan dari peserta didik sendiri, dan (4) hambatan fasilitas. Pada kevalidan jawaban peneliti menggunakan empat kode yaitu memantau langsung, kevalidan jawaban, jawaban peserta didik yang persis dan hasil tidak sahih berikut pada gambar lampiran quotations dari kode berdasarkan analisis atlasti.9.

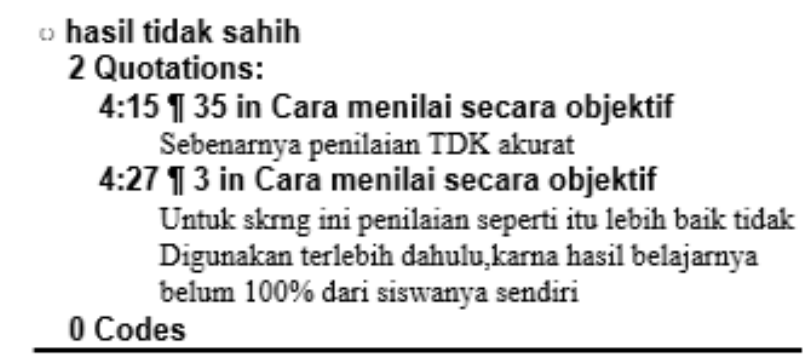

jawaban peserta didik yang persis

1 Quotations:

5:63 ๆ 24 in Hambatan

Terkadang jawaban anak 2 memiliki jawaban yg sama salahnya,mungkin karena mereka bertukar jawaban via WA, di mana jika di sekolah kita bisa mengontrol 0 Codes

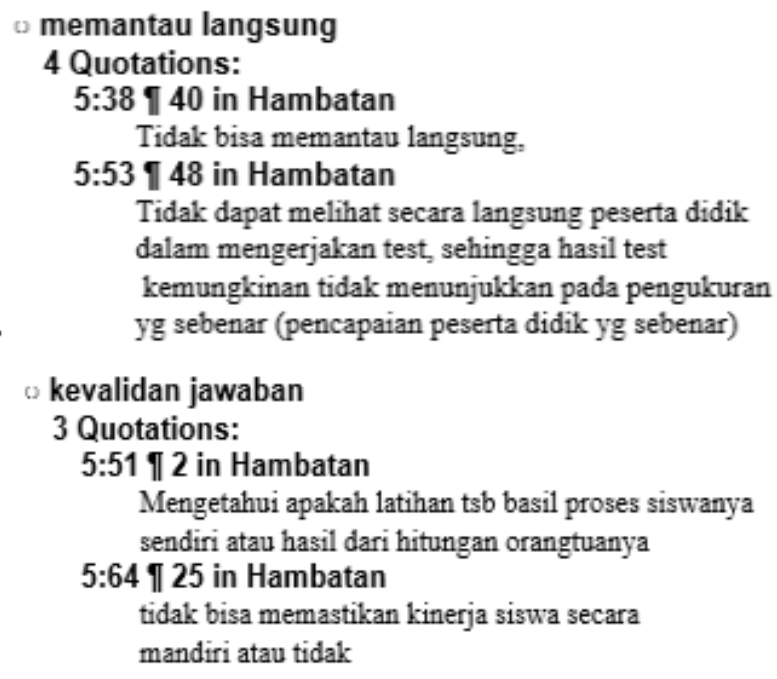

Gambar 8. Qutations dari kevalidan jawaban

Berdasarkan gambar 8 menunjukkan sebagian guru mengaku asesmen kurang objektif karena guru tidak bisa mengawasi secara langsung, sehingga ada kemungkinan peserta didik dibantu oleh orang tua, pendamping, atau saling menyontek antara peserta didik lainnya. Kerap kali guru menjumpai jawaban dari beberapa peserta didik yang persis. Guru sulit menilai pemahaman konsep peserta didik saat COVID-19. Sedangkan, dari hambatan dari peserta didik meliputi motivasi, pemaham konsep matematika secara parsial sehingga hasil asesmennya kurang baik (gambar 9).

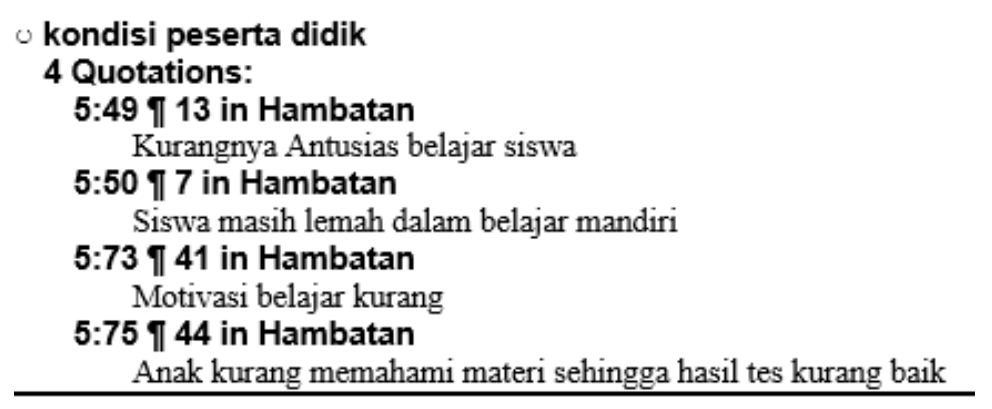

Gambar 9. Quotations Hambatan Kondisi Peserta Didik 
Pelaksanaan asesmen juga terkendala pada fasilitas seperi tidak semua peserta didik memiliki gadjet dan terkendala jaringan internet yang tidak stabil, dan kuota internet yang terbatas. Dilain sisi juga pelaksanaan asesmen dibatasi waktunya, berikut kutipan respon terbuka dari guru.

Responden 3: Waktu menilai dikurangi/dibatasi sama halnya belajar.

Responden 56: Frekuensi waktu bersama peserta didik yang sedikit

Responden 42: Waktu yang terbatas

\section{Pembahasan}

Berdasarkan hasil analisis data menunjukkan praktik asesmen kognitif matematika di masa pandemi COVID-19 tetap terlaksana. Studi Rigianti (2020) juga melaporkan hal serupa, walaupun dalam praktiknya guru merasa sulit menerapkan asesmen. Namun berbeda dengan studi Syah (2020) di masa pandemi COVID-19 ini, guru tidak menerapkan asesmen karena mengalami gangguan dalam proses pembelajaran langsung dan guru belum mempersiapkan asesmen dengan baik. Ayuni et al. (2020) memaparkan bahwa persiapan adalah komponen paling esensial walau dalam kondisi apapun. Dengan demikian terlaksananya praktik asesmen guru matematika dalam studi ini didukung oleh persiapan asesmen yang dilakukan guru. Pada dasarnya ada tiga tahapan dalam praktik asesmen yang harus diterapkan sebaik mungkin yaitu tahap persiapan, pelaksanaan, dan tindak lanjut (Pantiwati \& Nyono, 2020; Sutrisno, 2014; Pusmenjar, 2020). Maka berikut akan dibahas tahapan tersebut yang dilakukan oleh guru matematika dalam studi ini:

1. Pada tahap persiapan asesmen dalam studi ini menunjukkan guru telah merencanakan asesmen dengan baik ditinjau dari penyusunan instrumen dan menentukan bentuknya. Setengah dari responden menerapkan teknik tes, maka instrumen yang digunakan merupakan tes. 92,3\% guru atau hampir keseluruhan responden menggunakan soal berbentuk uraian dengan mempertimbangkan kemudahan dalam membuat butir soal dan memberi kesempatan pada peserta didik untuk menyajikan langkah-langkah pengerjaan pemecahan masalah sehingga memudahkan guru dalam menilai. Hal ini senada dengan pendapat Mardapi (2017) bahwa soal uraian memudahkan penilai dalam meninjau pemahaman peserta tes melalui langkah-langkah pengerjaannya. Achmetli et al (2018) juga mengungkapkan tes menjadi instrumen alternatif yang banyak digunakan guru dalam asesmen matematika karena prinsip kemudahannya.

2. Pada tahap pelaksanaan asesmen kognitif dominan dilakukan guru setiap mata pelajaran berlangsung atau setiap pekan, dilaksanakan secara langsung melalui home visit pada 
peserta didik sekolah dasar kelas rendah, sedangkan peserta didik sekolah dasar kelas tinggi hingga sekolah menengah dilaksanakan secara daring. Pemilihan teknik ini sesuai dengan kesimpulan studi Rufiana dan Nurhidayah (2020) serta Ahmad (2020) bahwa tes daring adalah model asesmen yang tepat diterapkan saat pandemi COVID-19. Proses pengukurannya dilaksanakan melalui beberapa aplikasi dengan prinsip kemudahan dan dapat diakses oleg guru, peserta didik dan pendamping. Dalam studi ini guru matematika lebih dominan menggunakan WhatsApp dan google classroom. Temuan ini senada dengan studi sebelumnya yang dilakukan oleh Asmuni (2020), Rigianti (2020), dan Setiawan (2020). Hal tersebut menunjukkan bahwa terlaksananya praktik asesmen dipengaruhi oleh teknologi dan penggunanya. Pernyataan sebelumnya didukung studi Salsabila et al (2020) yang mengungkapkan keberhasilan proses pembelajaran di masa krisis ini dipengaruhi oleh peran teknologi dan kualitas SDM. Dengan demikian ketersediaan fasilitas adalah kunci keberhasilan asesmen kognitif matematika secara daring.

3. Pada tindak lanjut asesmen, 85,9\% guru telah mengelompokan peserta didik dalam beberapa kategori, namun guru matematika memaparkan hasil asesmen yang telah dilaksanakan terjadi penurunan hasil pengukuran dari asesmen sebelum pandemi COVID19. Hal ini disebabkan kondisi peserta didik sendiri seperti kurang antusias dalam belajar, mereka masih lemah dalam belajar mandiri, dan penguasaan materi yang parsial. Senada dengan penyebab penurunan hasil pengukuran, sebelumnya Anugrahana (2020) juga menyebutkan kejenuhan dalam BDR berimplikasi pada proses memecahkan masalah pada soal secara asal-asalan, motivasi belajar mereka juga menurun.

Penurunan hasil asesmen juga disebabkan keterbatasan waktu, hambatan fasilitas seperti tidak tersedianya gadjet dan jaringan internet yang kurang stabil menyebabkan proses penyampaian materi tidak berlangsung seperti biasanya (Dwi et al., 2020; Purwanto et al., 2020; Chusna, 2020; Saefulmiah \& Saway, 2020; Wardani \& Ayriza, 2020), yang menyebabkan rendahnya pemahaman konsep peserta didik (Anugrahana, 2020; Syah, 2020), lalu berujung pada rendahnya pencapaian hasil belajar dalam asesmen. Padahal hasil asesmen dan proses pembelajaran matematika merupakan proses integral yang tak dapat dipisahkan dan saling memberi sumbangsi. Jika peserta didik memahami materi ajar maka hasil asesmen juga semakin baik (Achmetli, Schukajlow, \& Rakoczy, 2018).

Berbeda halnya dengan temuan Rigianti (2020) justru peserta didik mampu memecahkan soal dengan baik dan memperoleh nilai maksimal. Tapi hal tersebut masih menyisahkan pertanyaan bagi guru, apakah benar-benar hasil tersebut murni dari pemahaman peserta didik atau justru dari bantuan orang dewasa? Kondisi ini menimbulkan hambatan baru dalam praktik 
asesmen kognitif matematika saat pandemi COVID-19. Hal serupa terjadi pada guru matematika dalam studi ini yaitu kesulitan dalam menilai kemampuan peserta didik yang sebenarnya. Sebagian guru tidak dapat mengukur kemampuan peserta didik secara objektif atau akurat. Dalam temuan Syah (2020) juga mengemukakan asesmen saat pandemi COVID-19 dapat menyebabkan kesalahan pengukuran.

Hasil studi ini menunjukkan ada kecenderungan hasil jawaban peserta didik tidak valid karena hasil kerjasama dengan peserta didik laiinnya, atau dibantu orang tua/sanak saudara. Karena guru tidak dapat meninjau secara langsung proses pengerjaan tes, seperti pada temuan Anugrahana (2020). Dengan demikian prinsip asesmen dalam kondisi khusus yang merujuk pada keputusan Menteri Pendidikan dan Kebudyaan Republik Indonesia Nomor 719/P/2020 yaitu valid, reliabel, adil, fleksibel, otentik, dan teriintegrasi sulit terpenuhi. Berakibat sebagian guru mengalami kebingungan menentukan strategi pengajaran selanjutnya atau remidiasi, walaupun $85,9 \%$ guru matematika dalam studi ini mengungkapkan melakukan remediasi. Namun ada kemungkinan remediasinya kurang tepat.

Walaupun mengalami hambatan dalam mengukur pencapaian peserta didik secara objektif dan akurat, namun beberapa guru matematika dalam studi ini telah mengambil langkah alternatif, yaitu pemberian soal yang berbeda sembari adanya durasi pengerjaan, pemilihan teknik asesmen, pengawasan melalui video conference, asesmen tidak langsung dengan melihat keaktifan peserta didik selama pengajaran, tes lisan dan memperhatikan kesesuaian prosedur dan prinsip matematika yang digunakan. Beberapa langkah tersebut sesuai dengan saran Marhaeni (2020) yang menyampaikan jika ingin pelaksanaan asesmen secara daring tetap bermutu maka guru harus menghindarkan dari tugas-tugas asesmen yang bisa ditiru atau dicontek.

\section{Simpulan}

Praktik asesmen di masa pandemi COVID-19 lebih dominan dilaksanakan secara daring. Namun hasil asesmen tidak dapat menggambarkan kemampuan peserta didik yang sebenarnya karena prinsip asesmen valid, adil, reliabel dan otentik sulit terpenuhi. Hal tersebut dikarenakan adanya hambatan keterbatasan waktu, faktor internal dari peserta didik dan fasilitas. Namun ada beberapa upaya yang telah dilakukan sebagian guru untuk mendapatkan hasil yang sahih, yaitu: a) pemilihan teknik asesmen, b) pengawasan melalui video conference, c) asesmen tidak langsung dengan melihat keaktifan peserta didik selama pengajaran, dan d) tes lisan dan memperhatikan kesesuaian prosedur dan prinsip matematika yang digunakan. Sedangkan 
keterbatasan penelitian ini terletak pada instrumen yang digunakan dalam pengumpulan data hanya berdasarkan pada validitas tampang.

\section{Referensi}

Achmetli, K., Schukajlow, S., \& Rakoczy, K. (2018). Multiple solutions for real-world problems, experience of competence and students' procedural and conceptual knowledge. International Journal of Science and Mathematics Education, 17(8), 1605-1625. https://doi.org/10.1007/s10763-018-9936-5.

Ahmad, I. F. (2020). Alternative assessment in distance learning in emergencies spread of coronavirus disease (COVID-19). Jurnal Pedagogik, 07(1), 195-222. https://doi.org/10.33650/pip.v7i1.1136.

Aji, R. H. S. (2020). Dampak COVID-19 pada pendidikan di Indonesia: sekolah, keterampilan, dan proses pembelajaran. SALAM: Jurnal Sosial dan Budaya Syar-i, 7(5), 395-402. https://doi.org/10.15408/sjsbs.v7i5.15314.

Anugrahana, A. (2020). Hambatan, solusi dan harapan: pembelajaran daring selama masa pandemi COVID-19 oleh guru sekolah dasar. Scholaria: Jurnal Pendidikan dan Kebudayaan, 10(3), 282-289. https://doi.org/10.24246/j.js.2020.v10.i3.p282-289.

Asmuni. (2020). Problematika pembelajaran daring di masa pandemi COVID-19 dan solusi pemecahannya. Jurnal Paedagogy, 7(4), 281-288. https://doi.org/10.33394/jp.v7i4.2941.

Atsani, K. L. G. M. Z. (2020). Transformasi media pembelajaran pada masa pandemi covid-19. Jurnal Teknologi Pendidikan, 22(1), 65-70.

Ayuni, D., Marini, T., Fauziddin, M., \& Pahrul, Y. (2020). Kesiapan guru TK menghadapi pembelajaran daring masa pandemi COVID-19. Jurnal Obsesi: Jurnal Pendidikan Anak Usia Dini, 5(1), 414-421. https://doi.org/10.31004/obsesi.v5i1.579.

Black, P., \& Wiliam, D. (2009). Developing the theory of formative assessment. Educational Assessment, Evaluation and Accountability, 21(1), 5-31. https://doi.org/10.1007/s11092008-9068-5.

Chusna, P. A., \& Utami, A. D. M. (2020). Dampak pandemi COVID-19 terhadap peran orang tua dan guru dalam meningkatkan kualitas pembelajaran daring anak usia sekolah dasar. Premiere: Journal of Islamic Elementary Education, 2(1), 11-30.

Creswell, J. (2015). Riset pendidikan: perencanaan, dan evaluasi riset kualitatif \&kuantitatif (5th ed.). Yogyakarta: Pustaka Pelajar.

Dwi, B., Amelia, A., Hasanah, U., Putra, A. M., \& Rahman, H. (2020). Analisis keefektifan pembelajaran online di masa pandemi COVID-19. Jurnal Pendidikan Guru Sekolah Dasar, 5(3), 28-37.

Gonzalez, T., de la Rubia, M. A., Hincz, K. P., Comas-Lopez, M., Subirats, L., Fort, S., \& Sacha, G. M. (2020). Influence of COVID-19 confinement in students performance in higher education. https://doi.org/10.35542/osf.io/9zuac

Huang, C., Wang, Y., Li, X., Ren, L., Zhao, J., Hu, Y., Zhang, L., Fan, G., Xu, J., Gu, X., Cheng, Z., Yu, T., Xia, J., Wei, Y., Wu, W., Xie, X., Yin, W., Li, H., Liu, M., ... Cao, B. (2020). Clinical features of patients infected with 2019 novel coronavirus in Wuhan, China. The Lancet, 395(10223), 497-506. https://doi.org/10.1016/S01406736(20)30183-5.

Ihsanuddin. (2020). Fakta lengkap kasus pertama virus corona di Indonesia Halaman all Kompas.com. Diambil

dari https://nasional.kompas.com/read/2020/03/03/06314981/fakta-lengkap-kasus-pertamavirus-corona-di-indonesia?page $=$ all.

Looney, A., Cumming, J., van Der Kleij, F., \& Harris, K. (2018). Reconceptualising the role of 
teachers as assessors: teacher assessment identity. Assessment in Education: Principles, Policy and Practice, 25(5), 442-467. https://doi.org/10.1080/0969594X.2016.1268090.

Mardapi, D. (2017). Pengukuran, penilaian dan evaluasi pendidikan (2nd ed.). Yogyakarta: Parama Publishing.

Marhaeni, A. A. I. N. (2020). Webinar: Asesmen pembelajaran di era new normal.

Menteri Pendidikan dan Kebudayaan [Mendikbud]. (2020). Keputusan Menteri Pendidikan dan Kebudayaan nomor 719/P/2020 tentang pelaksanaan kurikulum pada satuan pendidikan dalam kondisi khusus. Jakarta: Kemendikbud.

Menteri Pendidikan dan Kebudayaan [Mendikbud]. (2020). Penyesuaian Kebijakan Pembelajaran di Masa Pandemi COVID-19. Jakarta: Kemendikbud.

Menteri Pendidikan dan Kebudayaan [Mendikbud]. (2020). Surat Edaran Menteri Pendidikan dan Kebudayaan Republik Indonesia, Pub. L. No. 35952/MPK.A/HK/2020. Jakarta: Kemendikbud.

NCTM. (2000). Principles and standards for school mathematics. Reston: NCTM.

Pantiwati, Y., \& Nyono, N. (2020). Asesmen autentik dalam kegiatan praktik pembelajaran sains. Prosiding Seminar Nasional Pendidikan Biologi V 2019, 385-392. Diambil dari http://research-report.umm.ac.id/.

Purwanto, A., Pramono, R., Asbari, M., Santoso, P. B., Wijayanti, L. M., Choi, C. H., \& Putri, R. S. (2020). Studi eksploratif dampak pandemi COVID-19 terhadap proses pembelajaran online di sekolah dasar. EduPsyCouns: Journal of Education, Psychology and Counseling, 2(1), 1-12. https://doi.org/10.31004/edukatif.v2i1.89.

Pusmenjar. (2020). Buku saku asesmen diagnosis kognitif berkala. Jakarta: Kemendikbud

Rigianti, H. A. (2020). Kendala pembelajaran daring guru sekolah dasar di Kabupaten Banjarnegara. Elementary School: Jurnal Pendidikan dan Pembelajaran Ke-SD-an, 7(2), 297-302. https://doi.org/10.31316/esjurnal.v7i2.768.

Rothan, H. A., \& Byrareddy, S. N. (2020). The epidemiology and pathogenesis of coronavirus disease (COVID-19) outbreak. Journal of Autoimmunity, 109(February), 102433. https://doi.org/10.1016/j.jaut.2020.102433.

Rufiana, I. S., \& Nurhidayah, D. A. (2020). Quizizz: Alternatif penilaian di masa pandemi COVID-19. 8(2), 95-108. https://doi.org/10.25139/smj.v8i2.3062.

Saefulmiah, R. M. I., \& Saway, M. H. M. (2020). Hambatan-hambatan pada pelaksanaan pembelajaran daring di SMA Riyadhul Jannah Jalan Cagak Subang. NUSANTARA, 2(3), 393-404.

Salsabila, U. H., Sari, L. I., Lathif, K. H., Lestari, A. P., \& Ayuning, A. (2020). Peran teknologi dalam pembelajaran di masa pandemi COVID-19. Al-Mutharahah: Jurnal Penelitian dan Kajian Sosial Keagamaan, 17(2), 188-198. $\underline{\text { https://doi.org/10.46781/al- }}$ mutharahah.v17i2.138.

Sandberg, B., \& Kecskes, K. (2017). Rubrics as a foundation for assessing student competencies: one public administration program's creative exercise. Journal of Public Affairs Education, 23(1), 637-652. https://doi.org/10.1080/15236803.2017.12002274.

Setiawan, A. R. (2020). Lembar kegiatan siswa untuk pembelajaran jarak jauh berdasarkan literasi saintifik pada topik penyakit coronavirus 2019 (COVID-19). Journal of Chemical Information and Modeling, 21(1), 1-9. https://doi.org/10.31237/osf.io/qb5w9.

Sutrisno, A. K. (2014). Analisis asesmen keterampilan berbicara dalam pembelajaran BIPA Program CLS 2013. Nosi, 2(1), 1-13.

Suurtamm, C., Thompson, Dennise, R., Kim, R. Y., Moreno, L. D., Sayac, N., Schukajlow, S., Silver, E., Ufer, S., \& Vos, P. (2016). Assessment in mathematics education large-scale assesment and classroom assessment. In Encyclopedia of Mathematics Education. https://doi.org/10.1007/978-94-007-4978-8_61.

Syah, R. H. (2020). Dampak COVID-19 pada pendidikan di Indonesia: sekolah, keterampilan, 
dan proses pembelajaran. SALAM: Jurnal Sosial dan Budaya Syar-i, 7(5). https://doi.org/10.15408/sjsbs.v7i5.15314.

UNESCO. (2020). Education: From disruption to recovery. Diambil dari https://en.unesco.org/covid19/educationresponse/

Wardani, A., \& Ayriza, Y. (2020). Analisis kendala orang tua dalam mendampingi anak belajar di rumah pada masa pandemi covid-19. Jurnal Obsesi: Jurnal Pendidikan Anak Usia Dini, 5(1), 772. https://doi.org/10.31004/obsesi.v5i1.705.

Wilsey, M., Kloser, M., Borko, H., \& Rafanelli, S. (2020). Middle school science teachers' conceptions of assessment practice throughout a year-long professional development Experience. Educational Assessment, 25(2), 136-158. https://doi.org/10.1080/10627197.2020.1756255.

World Healt Organization [WHO]. (2020). WHO Director-General's opening remarks at the media briefing on COVID-19 - 11 March 2020. Diambil dari https://www.who.int/dg/speeches/detail/who-director-general-s-opening-remarks-at-themedia-briefing-on-covid-19---11-march-2020

$\mathrm{Xu}, \mathrm{Y} ., \quad \&$ Brown, G. T. L. (2016). Teacher assessment literacy in practice: A reconceptualization. Teaching and Teacher Education, 58(Auguts), 149-162. https://doi.org/10.1016/j.tate.2016.05.010. 